\title{
Service quality in military peacekeeping mission as a determinant of customer's perceived value: Empirical evidence
}

\author{
Azman Ismail ${ }^{1}$, Norazila Mat ${ }^{1}$, Ahmad Azan Ridzuan ${ }^{2}$, Rosnan Herwina ${ }^{3}$ \\ ${ }^{1}$ Universiti Kebangsaan Malaysia, \\ ${ }^{2}$ National Defence University of Malaysia, \\ ${ }^{3}$ University Technology of MARA (Malaysia) \\ azisma08@gmail.com, ilaukm@gmail.com, azan6142@yahoo.com, \\ herwina@salam.uitm.edu.my
}

Received May, 2013

Accepted April, 2014

\section{Abstract}

Purpose: Previous studies have been employing SERVQUAL by Parasuraman, Zeithaml and Berry $(1985,1988)$ to measure service quality in various service sectors due to its generic nature. Understanding the relationship between service quality and customer's perceived value in non-business organizational settings is equally important with business setting as positive perception leads to favorable outcome. Hence, the aim of this study is to examine the relationship between service quality and perceived value.

Design/methodology/approach: The self-administered survey questionnaires were employed to gather data from Malaysian soldiers who involved in peacekeeping mission at a Middle Eastern country. The hypothesized model was analyzed using the SmartPLS 2.0 .

Findings: The outcomes of SmartPLS path model confirmed that that all service quality dimensions namely tangible, responsiveness, reliability, assurance, empathy did act as important determinants of customer's perceived value in the organizational sample.

Practical implications: The findings of this study may be used as guidelines by practitioners to formulate relevant and appropriate strategies in order to enhance 
quality of service delivery in agile organizations.

Originality/value: The work deals with service quality in non-business setting. Although the scale has been widely used, some modifications are generally needed in order to reflect specific characteristics of service sectors under study. The findings confirmed that in general SERVQUAL five dimensions are important determinants to the various service sectors.

Keywords: Workplace service quality, perceived value, Malaysian soldiers

Jel Codes: M12, N45

\section{Introduction}

Globalization creates a borderless world with increased used of information technology (IT). It opens up for new market, customer and employee globally. With the increase use of technology, making people become more knowledgeable and aware about their right and having more choice to choose. This lead to fast rapid changes in business environment and increased the competition. Owning to that, service quality is considered as a critical dimension to gain competitive advantages in this highly competitive situation (Shahin \& Samea, 2010). Providing excellent service quality grow to be a major area of attention to practitioners and managers in the various kinds of public and private sectors; in manufacturing and service industries (Sultan \& Wong, 2010; Sangeetha \& Mahalingam, 2011; Ladhari, Pons, Bressolles \& Zins, 2011; Sadeh, Mousavi, Garkaz \& Sadeh, 2011; Chen, Liu, Sheu \& Yang, 2012; Yogesh \& Satyanarayana, 2013) and in profit and non-profit organization (Sarstedt \& Schloderer, 2010; Serra, Serneels \& Barr, 2011). Service quality also have earned the attention of many researchers from diverse areas due to its strong impact on business performance (Abdullah, Suhaimi, Sabah \& Hamali, 2010; Rachel, Andy, Yeung \& Cheng, 2010; Williams \& Naumann, 2011) through customer satisfaction, loyalty and perceive value (Norizan \& Nor Asiah, 2010; Boksberger \& Melsen, 2011; Siddiqi, 2011; Chang \& Wang, 2011; Ryu, Lee \& Kim, 2012; Razavi, Safari \& Shafie, 2012; B. Adams, Steven, Dong \& Dresner, 2012; Hafeez \& Muhammad, 2012; Hameed, 2013) and from employee satisfaction, empowerment, trust and loyalty (Kimpakorn \& Tocquer, 2010; Turkyilmaz et al., 2011; Gazzoli, Hancer \& Park, 2010; Lu, Barriball, Zhang \& While, 2012; Kim, Lee, Murrmann \& George, 2012) that lead to organisation profitability (B. Adams et al., 2012). With the increased role of service sector as the main contributor for economic development in both developed and developing countries, this situation has made the evaluation of service quality continue to be relevant to enhance the understanding on the definition, modelling, measurement, new perspective and issues of 
service quality and contribute to development of sound base for the researchers.

Quality is a multi-dimensional construct and may be interpreted based on language and organizational views. In terms of language, it is often related to as conformance to requirements (Crosby, 1978), fitness for use (Juran, 1988), one that satisfies the customer (Eiglier \& Langeard, 1987), and zero defects in a service delivery system (Crosby, 1978). In an organisational perspective service quality is an indicator for corporate competitiveness (Rachel et al., 2010 Williams \& Naumann, 2011). Service quality is normally viewed as a long-run overall evaluation (Zeithaml, 1988; Parasuraman et al., 1988) and an overall appraisal of service at multiple levels in an organisation (Sureshchandar, Rajendran \& Anantharaman, 2002). For example, service quality exists when customers' expectations of service performance match their perceptions of the service received (Bolton \& Drew, 1991; Chang \& Wang, 2011; Yogesh \& Satyanarayana, 2013).

Service quality is a cognitive evaluation of customers' perceptions and expectations on quality of service deliver that impact organization performance through customer satisfaction (Abdullah et al., 2010; Rachel et al., 2010; Williams \& Naumann, 2011; Gallarza et al., 2011). Several conceptual models have been developed for measuring service quality and one of the most prevailing models in the service management literature is service quality gap (Parasuraman et al., 1985). During the period of 1984 until 2010 many services quality models being develop like Technical and functional quality model (Gronroos, 1984); Attribute service quality model (Haywood-Farmer, 1988); Performance only model (Cronin \& Taylor, 1992); Ideal value model of service quality (Mattsson, 1992); IT alignment model (Berkley \& Gupta, 1994); Attribute and overall affect model (Dabholkar, 1996); Retail service quality and perceived value model (Sweeney, Soutar \& Johnson, 1997); Service quality, customer value and customer satisfaction model (Oh, 1999); Internal service quality model (Frost \& Kumar, 2000); Model of e-service quality (Santos, 2003) and many more with the primary aim of these models is to enable the management to understand and enhance the quality of the organization and its offering. Jose, Martínez and Martínez (2010) has classified all those model into three main groups which they name as:

- Multidimensional reflective model

- Multidimensional formative models and

- Multidimensional formative-reflective model.

Many scholars, such as Parasuraman et al. (1988), Juwaheer and Ross (2003), Walker, Johnson and Leonard (2006), Ismail, Abdullah and Francis (2009), and Khan (2010) highlight 
that service quality have five important characteristics: tangible, responsiveness, empathy, assurance and reliability. Firstly, tangible is often described as being where a particular service provider provides good facilities, equipment, personnel and communication materials when delivering services. Secondly, responsiveness is often defined as the willingness of a service provider to provide the service quickly and accurately. Thirdly, empathy is related to caring, attention and understanding the customers' needs when providing services. Fourthly, assurance refers to credibility, competence and security in delivering services. Finally, reliability is frequently seen as the ability of the service provider to implement a promised service dependably and accurately.

Surprisingly, a thorough review of quality management programmes reveals that the ability of service providers to properly implement service quality in carrying out a job may have a significant impact on customer's perceived value (Caruana Money \& Berthon, 2000; Varki \& Colgate, 2001; Chang \& Wang, 2011; Sadeh et al., 2011; Ryu et al., 2012; Razavi et al., 2012). Perceived value can be defined based on organizational and customer perspectives. In an organizational perspective, perceived value is defined as trade-off between what customers receive, such as quality, benefits, and utilities, and what they sacrifice, such as price, opportunity cost, time, and efforts (Cronin, Brady \& Hult, 2000; Kuo, Wu \& Deng, 2009; Tung, 2004). While, according to a customer's perspective, perceived value is a construct that consist of five important dimensions: social, emotional, functional, epistemic, and conditional (Sheth, Newman \& Gross, 1991; Wang, Lo \& Yang, 2004). The combination of these values has motivated a customer to recognize and appreciate the utility of a product given by a 'service provider', which may fulfil his/her expectations (Foster, 2004; Heininen, 2004; Walker et al., 2006).

Within a quality management model, many scholars concur that service quality dimensions, namely tangible, reliability, responsiveness, assurance, empathy and customer's perceived value are different, but highly interrelated constructs. For example, the ability of the service provider to appropriately implement tangible, reliability, responsiveness, assurance and empathy in delivering services may lead to higher customer's perceived value about the quality programs (Sureshchandar et al., 2002; Rachel et al., 2010; Williams \& Naumann, 2011). Even though the nature of this relationship is important, not much is known about the role of service quality as a determinant of the customer's perceived value in the workplace service quality models (Ladhari \& Morales, 2007; Wang et al., 2004; Chang \& Wang, 2011; Ryu et al., 2012; Razavi et al., 2012; B. Adams et al., 2012; Hafeez \& Muhammad, 2012; Hameed, 2013).

Many scholars uncover that the role of service quality as a determinant is given less emphasis in previous studies because they have given more attention on the conceptual debates of 
service quality features. Moreover, little concentration was given on the use of a simple correlation method to assess the customer's reactions on the implementation of service quality programs in the workplace. Consequently, outcomes from these studies have offered inadequate useful evidence to be used as guidelines by practitioners in formulating relevant and appropriate strategies for enhancing the success of service quality in agile organizations (Eggert \& Ulaga, 2002; Kuo et al., 2009; Ismail et al., 2009; Delgado, Ferreira \& Branco, 2010; Khan, Kashif-Ur-Rehman, Ijaz-Ur-Rehman, Safwan \& Ahmad, 2011). Thus, it has motivated the researchers to further explore the gap of the literature by quantifying the relationship between service quality dimensions namely tangible, responsiveness, reliability, assurance, empathy and customer's perceived value.

\section{Literature Review}

This section provides theoretical and empirical evidence supporting the conceptual framework and hypotheses for this study.

\subsection{Relationship between Service Quality and Customer's Perceived Value}

Several extant studies about service quality were conducted using different samples such as 80 personnel interviews with customers of the telecommunication industry in China (Wang et al., 2004), 1500 hotel customers from selected hotels in Mauritius (Hu, Kandampully \& Juwaheer, 2009), questionnaires survey from 125 luxury hotel customers of Pakistan (Raza, Siddiquei, Awan \& Bukhari, 2012), 763 public transit passengers in Taiwan (Lai \& Chen, 2011) and 537 health care consumers in Niger health care market (Saibou \& Kefan, 2010). Findings from these studies reported that the ability of service providers to appropriately implement tangible, responsiveness, reliability, assurance and empathy in delivering services had been essential factor that could enhance customer's perceived value in the respective organizations (Hu et al., 2009; Lai \& Chen, 2011; Raza et al., 2012; Saibou \& Kefan, 2010; Wang et al., 2004).

These studies support the notion of service quality theory. For example, the service quality model devised by Parasuraman et al. (1985) conceptually explains that matching service quality standards and customers' standards may decrease the service performance gap and increase positive customer attitudes, especially perceived value about the quality programs. Besides that, J.S. Adams's (1963) equity theory highlights that fair treatments as a factor that may increase an individual's perceived value about the allocation of resources (e.g., quality programs). The essence of these theories is to emphasises consumers perceptions of justice and fairness of the service delivery (Boksberger \& Melsen, 2011; Chen et al., 2012). For 
example, application of these theories in the workplace service quality framework shows that the ability of service providers to appropriately implement tangible, responsiveness, reliability, assurance and empathy in doing job may lead to higher customer's perceived value in organizations (Hu et al., 2009; Saibou \& Kefan, 2010; Wang et al., 2004).

\subsection{Conceptual Framework and Research Hypothesis}

The literature has been used as foundation to develop a conceptual framework for this study as illustrated in Figure 1.

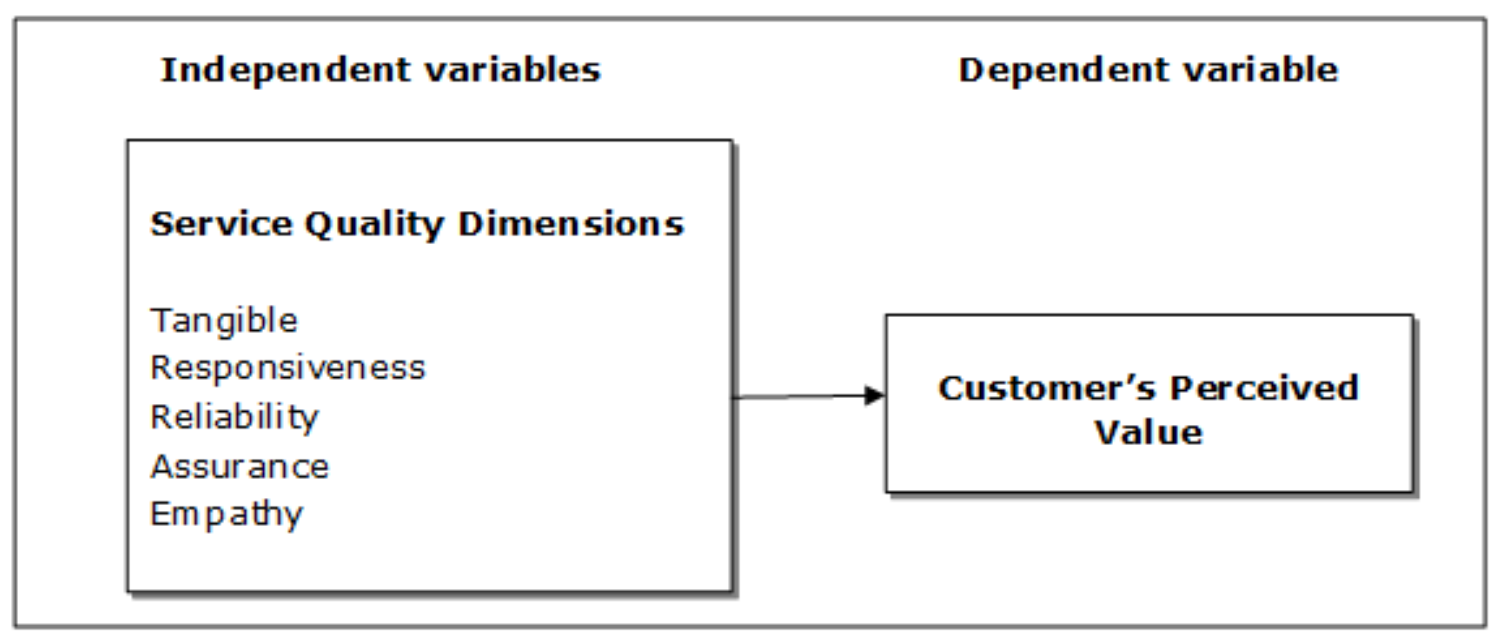

Figure 1. Relationship between service quality and customer's perceived value

Based on the framework, it can be hypothesized that:

- $\mathrm{H} 1$ : There is a positive relationship between tangible and customer's perceived value.

- $\mathrm{H} 2$ : There is a positive relationship between responsiveness and customer's perceived value.

- H3: There is a positive relationship between reliability and customer's perceived value.

- H4: There is a positive relationship between assurance and customer's perceived value.

- H5: There is a positive relationship between empathy and customer's perceived value. 


\section{Methodology}

\subsection{Research Design}

This study used a cross-sectional research design which allowed the researchers to integrate the service quality literature, the pilot study and the actual survey as a main procedure to gather data for this study. Using this procedure increases the ability to gather accurate data, less bias data and high quality data (Creswell, 2012; Sekaran \& Bougie, 2010). This study was conducted at a conflicting Middle Eastern country. The United Nation Headquarters' (Peacekeeping Operations) gave a permission to MALBATT Headquarters to send armed forces contingent in order to maintain and enforce peace in the country. Under this peacekeeping mission, MALBATT Headquarters are given important tasks and responsibilities to support the operation of armed forces troops that are deployed in the country. For confidential reasons, the name of the country is kept anonymous.

At the initial stage of data collection, a survey questionnaire was drafted based on the workplace service quality literature. After that, the pilot study was conducted by discussing the survey questionnaires with five experienced officers, namely a MALBATT commander, a commanding officer, an officer commanding, an administrative officer and a logistic staff officer who have good knowledge and experiences about the peacekeeping mission at a Middle Eastern country. The information gathered from the officers was used to improve the content and format of survey questionnaires for an actual research. Hence, a back translation technique was used to translate the content of questionnaires in Malay and English languages in order to increase the validity and reliability of the instrument (Creswell, 2012; Sekaran \& Bougie, 2010).

\subsection{Measures}

The self-administered survey questionnaire had three sections. First section focuses on demographic variables. Second section, tangible, responsiveness, reliability, assurance and empathy had 21 items that were modified from the Parasuraman et al.'s (1985) SERVQUAL instrument. Third section, customer's perceived value had 5 items that were modified from the customer's perceived value (Caruana et al., 2000; Eggert \& Ulaga, 2002; Foster, 2004; Tung, 2004). All these items were measured using a 7-item scale ranging from "very strongly disagree" (1) to "very strongly agree" (7). Demographic variables were used as the controlling variables because this study focused on soldier attitudes. 


\subsection{Sample}

This study obtained an official approval from the United Nation Headquarters' (Peacekeeping Operations) and Malaysian Ministry of Defence. These organizations allowed the researchers to conduct the survey, but the list of soldiers was not provided to the researchers. This situation did not allow the researchers to randomly select respondents. As a result, a convenient sampling technique was employed to distribute the survey questionnaires to 540 soldiers who involved in the peacekeeping mission at a Middle Eastern country. From the number, 341 usable questionnaires were returned to the researchers, yielding 63 percent response rate. The survey questionnaires were answered by participants based on their consents and on a voluntarily basis. The number of this sample exceeds the minimum sample of 30 participants as required by probability sampling technique, showing that it may be analyzed using inferential statistics (Creswell, 2012; Sekaran \& Bougie, 2010).

\subsection{Data Analysis}

The SmartPLS 2.0 was employed to assess the validity and reliability of the instruments and thus test the research hypotheses (Henseler, Ringle \& Sinkovics, 2009; Ringle, Wende \& Will, 2005). The main advantage of using this method may deliver latent variable scores, avoid small sample size problems, estimate every complex models with many latent and manifest variables, hassle stringent assumptions about the distribution of variables and error terms, and handle both reflective and formative measurement models (Henseler et al., 2009; Ringle et al., 2005).

The SmartPLS path model was employed to assess the path coefficients for the structural model using standardized beta $(\beta)$ and $\mathrm{t}$ statistics $(* \mathrm{t}>1.96 ; * * \mathrm{t}>2.576 ; * * * \mathrm{t}>3.29)$. The procedure of analyzing data is: first, construct and item validities were determined using convergent and discriminant validity analyses. Second, construct reliability was assessed by Cronbach alpha and composite reliability analyses. Third, the structural model is assessed by examining the path coefficients using standardized betas $(\beta)$ and t statistics. In addition, R2 is used as an indicator of the overall predictive strength of the model. The value of R2 are considered as follows; 0.19 (weak), 0.33 (moderate) and 0.67 (substantial) (Chin, 1998; Henseler et al., 2009). Thus, a global fit measure is conducted to validate the adequacy of PLS path model globally based on Wetzels, Odekerken-Schroder and Van Oppen's (2009) global fit measure. If the results of testing hypothesized model exceed the cut-off value of 0.36 for large effect sizes of $R^{2}$, showing that it adequately support the PLS path model globally (Wetzels et al., 2009). 


\section{Results}

\subsection{Sample Profile}

Table 1 shows that the majority respondent characteristics were males (97.1\%), other ranks (94.4\%), served in the Army (79.8\%), ages between 26 to 30 years old (58.9\%), married status $(55.7 \%)$, served $6-10$ years $(46.3 \%)$, SPM/MCE/SPVM holders $(71 \%)$, and first time serving under the United Nation (98.2\%).

\begin{tabular}{|c|c|c|c|}
\hline Respondent Profile & Sub Profile & Frequency & Percentage \\
\hline \multirow{2}{*}{ Sex } & Male & 331 & 97.1 \\
\hline & Female & 10 & 2.9 \\
\hline \multirow{2}{*}{ Rank } & Officer & 19 & 5.6 \\
\hline & Other rank & 322 & 94.4 \\
\hline \multirow{4}{*}{ Services } & Army & 272 & 79.8 \\
\hline & Navy & 24 & 7.0 \\
\hline & Air Force & 25 & 7.3 \\
\hline & Brunei Army & 20 & 5.9 \\
\hline \multirow{5}{*}{ Age } & Less than 25 years & 4 & 1.2 \\
\hline & $26-30$ years & 201 & 58.9 \\
\hline & $31-40$ years & 126 & 37 \\
\hline & $41-50$ years & 10 & 2.9 \\
\hline & More than 51 years & - & - \\
\hline \multirow{3}{*}{ Marital Status } & Bachelor & 146 & 42.8 \\
\hline & Married & 190 & 55.7 \\
\hline & Divorced & 5 & 1.5 \\
\hline \multirow{5}{*}{ Length of service } & Less than 5 years & 23 & 6.7 \\
\hline & $6-10$ years & 158 & 46.3 \\
\hline & $11-15$ years & 90 & 26.4 \\
\hline & $16-21$ years & 64 & 18.8 \\
\hline & More than 22 years & 6 & 1.8 \\
\hline \multirow{6}{*}{ Education } & Degree & 8 & 2.3 \\
\hline & Diploma & 20 & 5.9 \\
\hline & STPM/HSC & 6 & 1.8 \\
\hline & SPM/MCE/SPVM & 242 & 71 \\
\hline & SRP/PMR/LCE & 45 & 13.2 \\
\hline & Others & 20 & 5.9 \\
\hline \multirow{3}{*}{$\begin{array}{c}\text { Frequency of Serving } \\
\text { under the United } \\
\text { Nation }\end{array}$} & First time & 335 & 98.2 \\
\hline & Second times & 4 & 1.2 \\
\hline & More than 3 times & 2 & 0.6 \\
\hline
\end{tabular}

Note: SPM/MCE: Sijil Pelajaran Malaysia/ Malaysia Certificate of Education; STPM/HSC: Sijil Tinggi Pelajaran Malaysia/ Higher School Certificate; PMR/SRP/LCE: Penilaian Menengah Rendah/Sijil Rendah Pelajaran/Lower School Certificate

Table 1. Profile of respondents $(n=341)$ 


\subsubsection{Validity and Reliability Analyses for the Instrument}

Table 2 shows the results of convergent and discriminant validity analyses. All constructs had the values of average variance extracted ( $A V E$ ) larger than 0.5 indicating that the met the acceptable standard of convergent validity (Barclay, Higgins \& Thompson, 1995; Fornell \& Larcker, 1981; Henseler et al., 2009). Besides that, all constructs had the values of AVE square root in diagonal were greater than the squared correlation with other constructs in off diagonal, showing that all constructs met the acceptable standard of discriminant validity (Henseler et al., 2009).

\begin{tabular}{|c|c|c|c|c|c|c|c|}
\hline & AVE & Assurance & Empathy & $\begin{array}{l}\text { Perceived } \\
\text { Value }\end{array}$ & Reliability & $\begin{array}{l}\text { Responsive- } \\
\text { ness }\end{array}$ & Tangible \\
\hline Assurance & 0.650501 & 0.807 & & & & & \\
\hline Empathy & 0.736249 & 0.602127 & 0.858 & & & & \\
\hline Perceived Value & 0.660627 & 0.617055 & 0.712318 & 0.813 & & & \\
\hline Reliability & 0.644568 & 0.516136 & 0.473623 & 0.520507 & 0.803 & & \\
\hline Responsiveness & 0.647205 & 0.626690 & 0.558154 & 0.519738 & 0.614420 & 0.804 & \\
\hline Tangible & 0.613077 & 0.271991 & 0.323377 & 0.315715 & 0.356603 & 0.330304 & 0.783 \\
\hline
\end{tabular}

Table 2. Fornell-Larcker Criterion Test

\begin{tabular}{|c|c|c|c|c|c|c|}
\hline Construct/Items & Assurance & Empathy & $\begin{array}{c}\text { Perceived } \\
\text { Value }\end{array}$ & Reliability & Responsiveness & Tangible \\
\hline Comfortable & 0.764513 & 0.474956 & 0.479537 & 0.455775 & 0.481908 & 0.212627 \\
\hline Polite & 0.802493 & 0.481127 & 0.481163 & 0.412586 & 0.514211 & 0.244023 \\
\hline Confident & 0.841491 & 0.460299 & 0.506539 & 0.379273 & 0.495002 & 0.190916 \\
\hline No complaint & 0.803174 & 0.491941 & 0.482369 & 0.374472 & 0.484431 & 0.193215 \\
\hline Believe & 0.819044 & 0.518338 & 0.534983 & 0.457601 & 0.548302 & 0.254114 \\
\hline Cooperation & 0.505102 & 0.857821 & 0.619182 & 0.419062 & 0.467264 & 0.251573 \\
\hline Need & 0.505587 & 0.840688 & 0.577771 & 0.379198 & 0.447576 & 0.255094 \\
\hline Understanding & 0.554511 & 0.886899 & 0.618524 & 0.397386 & 0.513451 & 0.305872 \\
\hline Delivery & 0.501057 & 0.846046 & 0.627076 & 0.427930 & 0.485391 & 0.295729 \\
\hline Benefit & 0.450400 & 0.582287 & 0.762044 & 0.441015 & 0.454392 & 0.243386 \\
\hline Good value & 0.476029 & 0.589266 & 0.838889 & 0.422423 & 0.350778 & 0.229717 \\
\hline Fairness & 0.517565 & 0.637484 & 0.834918 & 0.415775 & 0.416192 & 0.286380 \\
\hline Adequate information & 0.564499 & 0.567758 & 0.854149 & 0.439616 & 0.409266 & 0.264244 \\
\hline Convenient & 0.496591 & 0.510525 & 0.769434 & 0.395944 & 0.489724 & 0.257677 \\
\hline Solving & 0.412580 & 0.400697 & 0.430287 & 0.861663 & 0.497240 & 0.314460 \\
\hline Good service & 0.436689 & 0.420058 & 0.402821 & 0.827031 & 0.512645 & 0.365579 \\
\hline Schedule & 0.385869 & 0.309549 & 0.418923 & 0.780820 & 0.403540 & 0.257874 \\
\hline Performance & 0.421012 & 0.389598 & 0.416263 & 0.736308 & 0.558013 & 0.207464 \\
\hline Feedback & 0.473098 & 0.401541 & 0.369583 & 0.492097 & 0.813446 & 0.247862 \\
\hline Priority & 0.501108 & 0.489691 & 0.420572 & 0.427085 & 0.793724 & 0.377189 \\
\hline Take care & 0.492266 & 0.381712 & 0.390547 & 0.554785 & 0.834611 & 0.201767 \\
\hline Urgent action & 0.536456 & 0.501534 & 0.472898 & 0.501383 & 0.774952 & 0.230990 \\
\hline Adequate equipment & 0.235473 & 0.319366 & 0.303427 & 0.263631 & 0.226890 & 0.835446 \\
\hline Suitable equipment & 0.174049 & 0.266358 & 0.212050 & 0.210291 & 0.234880 & 0.824060 \\
\hline Suitable location & 0.220112 & 0.179727 & 0.228672 & 0.336733 & 0.288797 & 0.747011 \\
\hline $\begin{array}{l}\text { Communication } \\
\text { network }\end{array}$ & 0.214399 & 0.229202 & 0.226212 & 0.309690 & 0.295822 & 0.719191 \\
\hline
\end{tabular}

Table 3. Factor Loadings and Cross Loadings for the Constructs 
Table 3 shows the factor loadings and cross loadings for different constructs. The correlation between items and factors had higher loadings than other items in the different constructs. The loadings of variables more strongly on their own constructs in the model, greater than 0.7 are considered adequate (Chin, 1998; Fornell \& Larcker, 1981; Gefen \& Straub, 2005; Henseler et al., 2009). In sum, the measurement model has met the validity criteria.

Table 4 shows the results of reliability analysis for the instrument. The composite reliability and Cronbach's Alpha had values of greater than 0.8, indicating that the measurement scale used in this study had high internal consistency (Henseler et al., 2009; Nunally \& Benstein, 1994; Sekaran \& Bougie, 2010).

\begin{tabular}{|l|c|c|}
\hline Construct & Composite Reliability & Cronbachs Alpha \\
\hline Assurance & 0.902885 & 0.865405 \\
\hline Customer Satisfaction & 0.917770 & 0.880454 \\
\hline Empathy & 0.906642 & 0.870866 \\
\hline Reliability & 0.878475 & 0.814426 \\
\hline Responsiveness & 0.879987 & 0.818821 \\
\hline Tangible & 0.863251 & 0.789347 \\
\hline
\end{tabular}

Table 4. Composite Reliability and Cronbach's Alpha

\subsubsection{Analysis of the Constructs}

Table 5 shows the results of Pearson correlation analysis and descriptive statistics. The means for the variables range from 5.1 to 5.5 signifying the levels of tangible, reliability, responsiveness, assurance, empathy and perceived value ranging from high (4) to highest level (7). The correlation coefficients for the relationship between the independent variables (i.e., tangible, reliability, responsiveness, assurance, and empathy) and the dependent variable (i.e., perceived value) were less than 0.90 , indicating the data were not affected by serious collinearity problem (Hair, Black, Babin, Anderson \& Tatham, 2006).

\begin{tabular}{|c|c|c|c|c|c|c|c|c|}
\hline \multirow{2}{*}{ Variable } & \multirow{2}{*}{ Mean } & \multirow{2}{*}{$\begin{array}{l}\text { Standard } \\
\text { Deviation }\end{array}$} & \multicolumn{6}{|c|}{ Pearson Correlation Analysis ( $r$ ) } \\
\hline & & & 1 & 2 & 3 & 4 & 5 & 6 \\
\hline 1. Tangible & 5.1 & .81 & 1 & & & & & \\
\hline 2. Reliability & 5.5 & .68 & $.55^{* *}$ & 1 & & & & \\
\hline 3. Responsiveness & 5.5 & .68 & $.47^{* *}$ & $.70^{* *}$ & 1 & & & \\
\hline 4. Assurance & 5.4 & .71 & $.44^{* *}$ & $.62^{* *}$ & $.71^{* *}$ & 1 & & \\
\hline 5. Empathy & 5.4 & .77 & $.44^{* *}$ & $.58^{* *}$ & $.67^{* *}$ & $.69^{* *}$ & 1 & \\
\hline 6. Perceived Value & 5.5 & .72 & $.47^{* *}$ & $.65^{* *}$ & $.62^{* *}$ & $.71^{* *}$ & $.76^{* *}$ & 1 \\
\hline
\end{tabular}

Note: Significant at $* * \mathrm{p}<0.01$. Reliability Estimation is Shown in a Diagonal

Table 5. Pearson Correlation Analysis and Descriptive Statistics 


\subsubsection{Outcomes of Testing Hypotheses 1, 2, 3, 4 and 5}

Table 6 shows that the quality of model predictions in the analysis was demonstrated by the score of $\mathrm{R}$ square. The inclusion of the service quality features in the analysis showed that tangible had explained 10 percent in the variance of customer's perceived value, responsiveness had explained 28 percent in the variance of customer's perceived value, reliability had explained 27 percent in the variance of customer's perceived value, assurance had explained 38 percent in the variance of customer's perceived value, and empathy had explained 51 percent in the variance of customer's perceived value.

Specifically, the outcomes of testing hypothesis using SmartPLS displayed five important findings: first, tangible significantly correlated with customer's perceived value ( $\beta=317$; $t=6.329)$, therefore $H 1$ was supported. Second, responsiveness significantly correlated with customer's perceived value $(\beta=0.530 ; t=12.217)$, therefore $\mathrm{H} 2$ was supported. Third, reliability significantly correlated with customer's perceived value $(\beta=0.521 ; t=11.701)$, therefore $\mathrm{H} 3$ was supported. Fourth, assurance significantly correlated with customer's perceived value ( $\beta=0.619 ; t=15.254)$, therefore $\mathrm{H} 4$ was supported. Fifth, empathy significantly correlated with customer's perceived value $(\beta=0.714 ; t=19.399)$, therefore $\mathrm{H} 5$ was supported. In sum, this result demonstrates that tangible, responsiveness, reliability, assurance, and empathy act as important determinants of customers' perceived value in the studied organizations.

In order to determine a global fit PLS path model, we carried out a global fit measure (GoF) based on Wetzels et al.'s (2009) guideline as follows: GoF=SQRT\{MEAN (Communality of Endogenous) $x$ MEAN $\left.\left(R^{2}\right)\right\}=0.621$, indicating that it exceeds the cut-off value of 0.36 for large effect sizes of $\mathrm{R}^{2}$. This result confirms that the PLS path model has better explaining power in comparison with the baseline values (GoF small=0.1, GoF medium=0.25, GoF large=0.36). It also provides adequate support to validate the PLS model globally (Wetzels et al., 2009). 


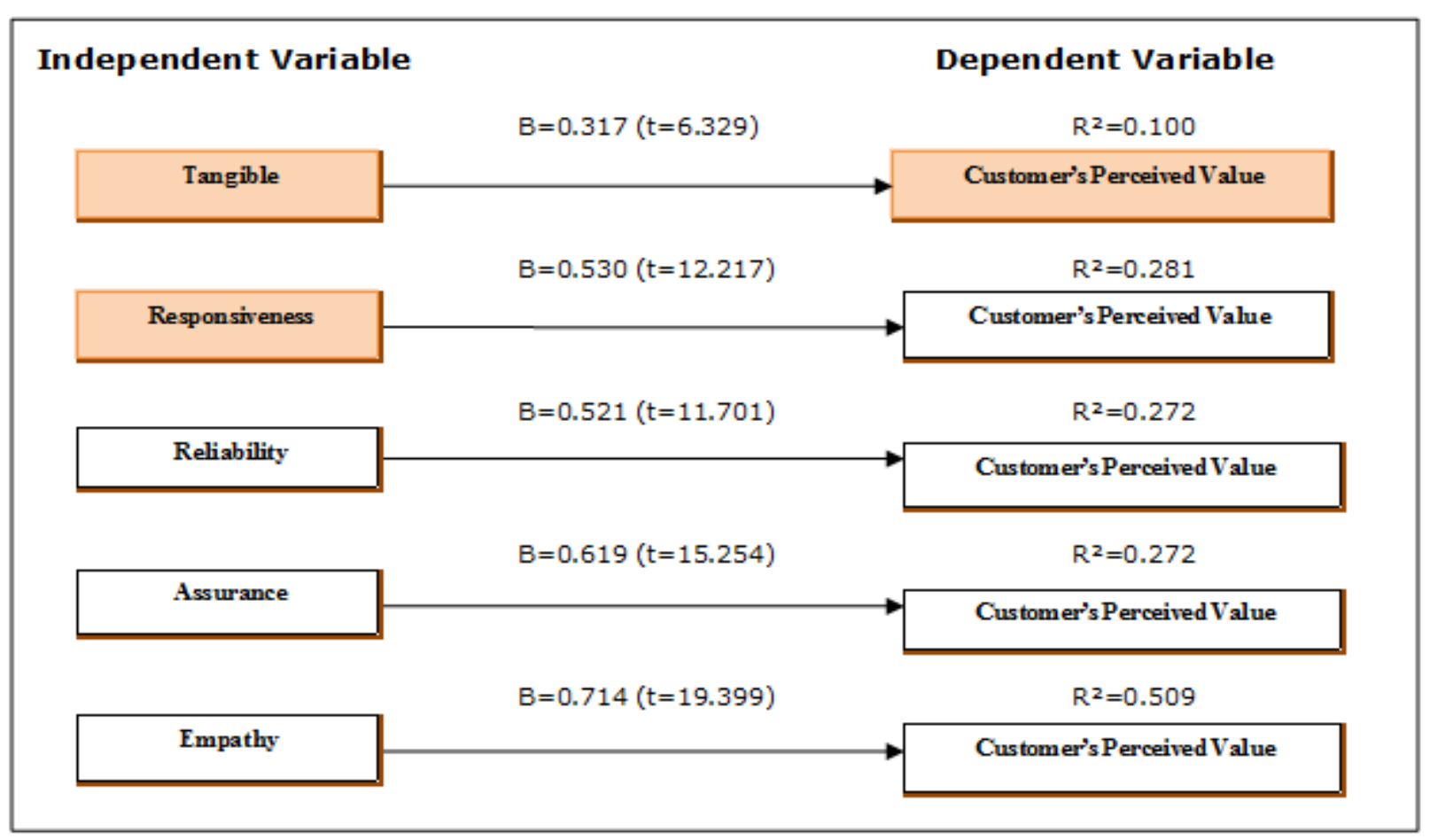

Note: Significant at $* \mathrm{t}>1.96 ; * * \mathrm{t}>2.576 ; * * * \mathrm{t}>3.29$

Table 6. The Results of SmartPLS Path Model Showing the Relationship between Service Quality and

Customer's Perceived Value

\section{Discussion and Implications}

The findings of this study show that service quality has been an important determinant of customer's perceived value in the organizational sample. In the context of this study, the service provider (i.e., MALBATT Headquarters) has taken a proactive action to plan, lead and monitor its service based on the broad policies and regulations set up by the United Nation (Peacekeeping Operation). The majority soldiers perceived that all service quality features, namely tangible, responsiveness, reliability, assurance and empathy have been well planned and implemented in delivering services to the soldiers who participating in operation, administration and logistics divisions. As a result of this implementation, it may lead to an enhanced customer's perceived value about the quality programs in the peacekeeping mission.

This study provides significant impacts on three major aspects: theoretical contribution, robustness of research methodology, and practical contribution. In terms of theoretical contribution, this study reveals that the ability of service provider to properly plan and implement tangible, responsiveness, reliability, assurance and empathy in delivering service have been important determinants of customer's perceived value in the studied organization. This finding has also supported and broadened studies by Parasuraman et al. (1985); Wang et 
al. (2004), Hu et al. (2009), Saibou \& Kefan (2010) Chang and Wang (2011), Ryu et al., (2012) and Razavi et al. (2012). A careful observation about the findings shows that the relationship between service quality features and customers' perceived value is significant, but the role of service quality features as an important predicting variable is low in the hypothesized model. This result may be indirectly affected by perceptions of different respondent characteristics. First, they may have different evaluations and acceptance about the importance of each service quality feature in helping them to achieve the goals of peacekeeping mission. Second, they may have dissimilar talents and capabilities to comply service quality guidelines and methods in accomplishing their peacekeeping duties and responsibilities. This situation may overrule the effectiveness of service quality in the peacekeeping mission.

Regarding the robustness of research methodology, the survey questionnaires used in this study have exceeded the minimum standard of validity and reliability analyses. This resulted to the production of accurate and reliable findings. With respect to practical contribution, the findings of this study can be used as guidelines by management to improve the service quality of peacekeeping missions in other conflicting countries. The possible suggestions are: firstly, quality service training programs for peacekeeping management staff need to be provided to increase their competencies in fulfilling front line soldier needs in the operation areas. Secondly, stress training programs to soldiers need to be provided in order to increase their skills in handling physiological and psychological stresses in the conflicting situations. Thirdly, foreign language training programs need to be provided to soldiers in order to enable them to communicate with foreign people who live in the conflicting countries. Fourthly, pay levels for peacekeeping management staff need to be increased in order to recognize their commitment in ensuring service quality for front line soldiers. Fifthly, recruitment and selection policies need to pay high attention on hiring soldiers who have good information technology skills in order to enable them handling and repairing sophisticated communication devices in the operation areas. If these suggestions are heavily considered this may attract, retain and motivate good soldiers to participate in peacekeeping mission operations.

\section{Conclusion}

This study proposed a conceptual framework based on the workplace service quality research literature. The confirmatory factor analysis confirmed that the instrument used in this study met the acceptable standards of validity and reliability analyses. Thus, the outcomes of SmartPLS path model confirmed that all service quality dimensions, namely tangible, responsiveness, reliability, assurance and empathy did act as important determinants of 
customer's perceived value in the organizational sample. This result has also supported and broadened the workplace service quality research literature mostly published in most Western countries. Therefore, current research and practice within the workplace service quality models needs to consider tangible, responsiveness, reliability, assurance and empathy as critical dimensions of the total quality organization domain. The findings of this study further suggest that the ability of service providers to appropriately implement the tangible, responsiveness, reliability, assurance and empathy in delivering services will strongly invoke positive subsequent attitudinal and behavioural outcomes (e.g., satisfaction, retention, loyalty, positive moral values, cooperation and service performance). Hence, these positive outcomes may lead to sustained and supported the organizational strategy and goals in an era of global conflicts and violence.

The conclusions drawn from the results of this study should consider the following limitations. Firstly, this study was a cross-sectional research design where the data was taken at one point of time within the duration of this study. In this sense, this research design did not capture the developmental issues (e.g., intra-individual change and restrictions of making inference to participants) and/or causal connections between variables of interest (Sekaran \& Bougie, 2010). Secondly, this study only examined the relationship between latent/unobserved variables (i.e., tangible, responsiveness, reliability, assurance, empathy and customer's perceived value) and the conclusion drawn from this study does not specify the relationship between specific indicators for the independent variable and dependent variable. Thirdly, the outcomes of SmartPLS path model have focused on the level of performance variation explained by the regression equations and it is also helpful to indicate the amount of dependent variable variation that is not explained (Henseler et al., 2009; Riggle, Edmondson \& Hansen, 2009). Although a substantial amount of variance in dependent measure that is explained by the significant predictors is identified, there are still a number of unexplained factors that can be incorporated to identify the causal relationships among variables and their relative explanatory power. Therefore, one should be cautious about generalizing the statistical results of this study. Finally, the sample of this study uses only the Malaysian armed forces contingent and they are selected by using a convenient sampling technique. The nature of this sample may decrease the ability of generalizing the results of this research to other organizational contexts.

The conceptual and methodological limitations of this study need to be deliberated when conducting future research. Firstly, this study sets up a foundation for study on correlation between service quality and customer's perceived value. It has raised many questions as well as endorsing initial findings. Several research areas can be further discovered as an outcome of this study. Secondly, the organizational (e.g., soldier groups from other countries) and 
personal (e.g., gender, age, education and position) variables as potential factors that can influence the effect of service quality on customer's perceived value needs to be further examined. Using these variables may provide meaningful perspectives for the understanding of how individual similarities and differences affect service quality programs within an organization. Thirdly, the cross-sectional research design has a number of shortcomings; therefore other research designs such as longitudinal studies could be employed as a procedure for collecting data and describing the patterns of change and the direction and magnitude of causal relationships between variables of interest. Fourthly, the findings of this study rely very much on the sample taken from a single organizational sector. To fully understand the effects of service quality on customer attitudes and behavior, more organizational sectors (e.g., armed forces contingents from other countries like the United States, France, Britain and Australia) need to be used in future research. Finally, other personal outcomes of customer's perceived value such as retention, loyalty and behavioral intention should be considered in future research because they are given more attention in considerable service quality literature (Ismail et al., 2009; Raza et al., 2012; Saibou \& Kefan, 2010). The importance of these issues needs to be further elaborated in future research.

\section{Acknowledgment}

The authors would like to thank the Ministry of Higher Education, Malaysia for sponsoring this research project.

\section{References}

ABDULLAH, F.; SUHAIMI, R.; SABAH, G.; HAMALI, J. (2010). Bank Service Quality (BSQ) Index. International Journal of Quality \& Reliability Management, 28(5): 542-555. http://dx.doi.org/10.1108/02656711111132571

ADAMS, J.S. (1963). Towards an understanding of inequality. Journal of Abnormal and Normal Psychology, 67: 422-436. http://dx.doi.org/10.1037/h0040968

BARCLAY, D.; HIGGINS, C.; THOMPSON, R. (1995). The Partial Least Squares (PLS) approach to causal modeling: Personal computer adoption and use as an illustration. Technology Study, 2(2): 285-309.

BERKLEY, B.J.; GUPTA, A. (1994). Improving Service Quality with Information Technology. International Journal of Information Management, 14: 109-121. http://dx.doi.org/10.1016/02684012(94)90030-2 
BOKSBERGER, P.E.; MELSEN, L. (2011). Perceived value: A critical examination of definitions, concepts and measures for the service industry. Journal of Services Marketing, 25(3): 229-240. http://dx.doi.org/10.1108/08876041111129209

BOLTON, R.N.; DREW, J.H. (1991). A longitudinal analysis of the impact of service changes on customer attitudes. Journal of Marketing, 55(1): 1-9. http://dx.doi.org/10.2307/1252199

CARUANA, A.; MONEY, A.H.; BERTHON, P.R. (2000). Service quality and satisfaction - the moderating role of value. European Journal of Marketing, 34(11/12): 1338-1352. http://dx.doi.org/10.1108/03090560010764432

CHANG, H.H.; WANG, H.W. (2011). The Moderating Effect Of Customer Perceived Value On Online Shopping Behaviour. Online Information Review, 35(3): 333-359.

http://dx.doi.org/10.1108/14684521111151414

CHEN, H.; LIU, J.Y.; SHEU, T.S.; YANG, M. (2012). The Impact Of Financial Services Quality And Fairness On Customer Satisfaction. Managing Service Quality, 22(4): 399-421. http://dx.doi.org/10.1108/09604521211253496

CHIN, W.W. (1998). The Partial Least Squares approach to Structural Equation Modeling. In R.H. Hoyle (Eds.). Statistical strategies for small sample research (pp.307-341). Thousand Oaks-California: Sage Publication, Inc.

CLOTTEY, T.A.; COLLIER, D.A. (2008). Drivers of Customer Loyalty in a Retail Store Environment. Journal of Service Science, 3rd Quarter. In CRONIN, J.J., BRADY, M.K., \& HULT, G.T.M. (2000). Assessing the effects of quality, value, and customer satisfaction on behavior intentions in service environments. Journal of Retailing, 76(2): 193-218.

CRESWELL, J.W. (2012). Educational Research: Planning, Conduct, and Evaluating Quantitative and Qualitative Research (Fourth Edition). Boston: Pearson.

CRONIN JR, J.J.; BRADY, M.K.; HULT, G.T.M. (2000). Assessing the effects of quality, value, and customer satisfaction on consumer behavioral intentions in service environments. Journal of Retailing, 76(2): 193-218. http://dx.doi.org/10.1016/S0022-4359(00)00028-2

CRONIN, J.J.; TAYLOR, S.A. (1992). Measuring Service Quality: A Reexamination and Extension. Journal of Marketing, 6: 55-68. http://dx.doi.org/10.2307/1252296

CROSBY, P.B. (1978). Quality is free - The Art of Making Quality Certain. New York: McGrawHill.

DABHOLKAR, P.A. (1996). Consumer Evaluations Of New Technology-Based Self-Service Options: An investigation of alternative models of service quality. International Journal of Research in Marketing, 13: 29-51. http://dx.doi.org/10.1016/0167-8116(95)00027-5 
DELGADO, C.; FERREIRA, M.; BRANCO, M.C. (2010). The Implementation of Lean Six Sigma in Financial Services Organizations. Journal of Manufacturing Technology Management, 21(4): 512-523. http://dx.doi.org/10.1108/17410381011046616

EGGERT, A.; ULAGA, W. (2002). Customer perceived value: A substitute for satisfaction in business markets?. Journal of Business and Industrial Marketing, 17(2/3): 107-118. http://dx.doi.org/10.1108/08858620210419754

EIGLIER, P.; LANGEARD, E. (1987). Servication: Le marketing des services. Paris: McGraw-Hill. FORNELL, C.; LARCKER, D.F. (1981). Evaluating structural equation models with unobservable variables and measurement error. Journal of Marketing Research, XVIII(February): 39-50. http://dx.doi.org/10.2307/3151312

FOSTER, S.T. (2004). Managing Quality: An Integrative Approach. New Jersey: Prentice Hall.

FROST, F.A.; KUMAR, M. (2000). INTSERVQUAL: an internal adaptation of the GAP model in a large service organization. Journal of Services Marketing, 14(5): 358-377.

http://dx.doi.org/10.1108/08876040010340991

GAZZOLI, G.; HANCER, M.; PARK, Y. (2010). The Role And Effect Of Job Satisfaction And Empowerment On Customers' Perception Of Service Quality: A Study In The Restaurant Industry. Journal of Hospitality \& Tourism Research, 34 (1): 56-77.

http://dx.doi.org/10.1177/1096348009344235

GEFEN, D.; STRAUB, D. (2005). A practical guide to factorial validity using PLS-Graph: Tutorial and annotated example. Communication of the Association for Information Systems, 16(1), 91-109.

GRONROOS, C. (1984). A Service Quality Model and Its Marketing Implications. European Journal of Marketing, 18(4): 36-44. http://dx.doi.org/10.1108/EUM0000000004784

HAFEEZ, S.; MUHAMMAD, B. (2012). The Impact Of Service Quality, Customer Satisfaction And Loyalty Programs On Customer's Loyalty: Evidence From Banking Sector Of Pakistan. International Journal of Business and Social Science, 3(16): 200-209.

HAIR, J.F.; BLACK, W.C.; BABIN, B.J.; ANDERSON, R.E.; TATHAM, R.L. (2006). Multivariate Data Analysis. Upper Saddle River: Pearson Prentice Hall.

HAMEED, F. (2013). The Effect of Advertising Spending on Brand Loyalty Mediated by Store Image, Perceived Quality and Customer Satisfaction: A Case of Hypermarkets. Asian Journal of Business Management, 5(1): 181-192.

HAYWOOD-FARMER, J. (1988). A Conceptual Model of Service Quality. International Journal of Operations \& Production Management, 8(6): 19-29. http://dx.doi.org/10.1108/eb054839 
HEININEN, K. (2004). Reconceptualizing customer perceived value: the value of time and place. Managing Service Quality, 14(2/3): 205-215.

http://dx.doi.org/10.1108/09604520410528626

HENSELER, J.; RINGLE, C.M.; SINKOVICS, R.R. (2009). The Use of Partial Least Squares Path Modeling in International Marketing. In: R.R. SINKOVICS \& P.N. GHAURI (Eds.), Advances in International Marketing (pp. 277-320). Bingley: Emerald.

HU, H.H.; KANDAMPULLY, J.; JUWAHEER, T.D. (2009). Relationships and impacts of service quality, perceived value, customer satisfaction, and image: An empirical study. The Service Industries Journal, 29(2): 111-125. http://dx.doi.org/10.1080/02642060802292932

ISMAIL, A.; ABDULLAH, M.M.; FRANCIS, S.K. (2009). Exploring the relationships among service quality features, perceived value and customer satisfaction. Journal of Industrial Engineering and Management, 2(1): 230-250. http://dx.doi.org/10.3926/jiem.2009.v2n1.p230-250

JOSE, A.; MARTINEZ, J.A.; MARTINEZ, L. (2010). Some Insights On Conceptualizing And Measuring Service Quality. Journal of Retailing and Consumer Services, 17(1): 29-42. http://dx.doi.org/10.1016/j.jretconser.2009.09.002

JURAN, J.M. (1988). Juran's Quality Control Handbook. Fremont, USA: McGraw-Hill.

JUWAHEER, T.D.; ROSS, D.L. (2003). A study of guest perceptions in Mauritius. International Journal of Hospitality Management, 15(2): 105-115.

KHAN, M.A. (2010). An Empirical Assessment of Service Quality of Cellular Mobile Telephone Operators in Pakistan. Asian Social science, 6(10): 164-177.

KHAN, M.A.; KASHIF-UR-REHMAN; IJAZ-UR-REHMAN; SAFWAN, N.; AHMAD, A. (2011). Modeling Link Between Internal Service Quality In Human Resources Management And Employees Retention: A Case Of Pakistani Privatized And Public Sector Banks. African Journal of Business Management, 5(3): 949-959.

KIM, B.C.; LEE, G.; MURRMANN, S.K.; GEORGE, T.R. (2012). Motivational Effects of Empowerment on Employees' Organizational Commitment: A Mediating Role of Management Trustworthiness. Cornell Hospitality Quarterly, 53(1): 10-19.

http://dx.doi.org/10.1177/1938965511426561

KIMPAKORN, N.; TOCQUER, G. (2010). Service Brand Equity And Employee Brand Commitment. Journal of Services Marketing, 24(5): 378-388.

http://dx.doi.org/10.1108/08876041011060486

KUO, Y.F.; WU, C.M.; DENG, W.J. (2009). The relationships among service quality, perceived value, customer satisfaction, and post-purchase intention in mobile value-added services. Computers in Human Behavior, 25(4): 887-896. http://dx.doi.org/10.1016/j.chb.2009.03.003 
LADHARI, R.; MORALES, M. (2007). The role of emotions in dining experience. Proceedings/Actes, 28(23): 80.

LADHARI, R.; PONS, F.; BRESSOlLES, G.; ZINS, M. (2011). Culture And Personal Values: How They Influence Perceived Service Quality. Journal of Business Research, 64(9): 951-957. http://dx.doi.org/10.1016/j.jbusres.2010.11.017

LAI, W-T.; CHEN, C-F. (2011). Behavioral intentions of public transit passengers- The roles of service quality, perceived value, satisfaction and involvement. Transport Policy, 18(2): 318-325. http://dx.doi.org/10.1016/j.tranpol.2010.09.003

LU, H.; BARRIBALL, K.L.; ZHANG, X.; WHILE, A.E. (2012). Job Satisfaction Among Hospital Nurses Revisited: A Systematic Review. International Journal of Nursing Studies, 49: 1017-1038. http://dx.doi.org/10.1016/j.ijnurstu.2011.11.009

MATTSSON, J. (1992). A Service Quality Model Based On Ideal Value Standard. International Journal of Service Industry Management, 3(3): 18-33.

http://dx.doi.org/10.1108/09564239210015148

NORIZAN, K.; NOR ASIAH, A. (2010). The Effect Of Perceived Service Quality Dimensions On Customer Satisfaction, Trust, And Loyalty In E-Commerce Settings: A Cross Cultural Analysis. Asia Pacific Journal of Marketing and Logistics, 22(3): 351-371.

http://dx.doi.org/10.1108/13555851011062269

NUNALLY, J.C.; BERNSTEIN, I.H. (1994). Psychometric Theory. New York: McGraw-Hill.

$\mathrm{OH}, \mathrm{H}$. (1999). Service quality, customer satisfaction and customer value: A holistic perspective. International Journal of Hospitality Management, 18: 67-82.

http://dx.doi.org/10.1016/S0278-4319(98)00047-4

PARASURAMAN, A.; ZEITHAML, V.A.; BERRY, L.L. (1985). A conceptual model of service quality and its implication for future research. Journal of Marketing, 49(Fall): 41-50. http://dx.doi.org/10.2307/1251430

PARASURAMAN, A.; ZEITHAML, V.A.; BERRY, L.L. (1988). SERVQUAL: A multiple scale for measuring consumer perceptions of service quality. Journal of Retailing, 64(Spring): 12-40.

RACHEL, W.Y.; ANDY, C.L.; YEUNG, T.C.; CHENG, E. (2010). An Empirical Study Of Employee Loyalty, Service Quality And Firm Performance In The Service Industry. International Journal of Production Economics, 124(1): 109-120. http://dx.doi.org/10.1016/j.jpe.2009.10.015

RAZA, M.A.; SIDDIQUEI, A.N.; AWAN, H.M.; BUKHARI, K. (2012). Relationship between service quality, perceived value, satisfaction and revisit intention in hotel industry. Interdisciplinary Journal of Contemporary Research in Business, 4(8): 788-805. 
RAZAVI, S.M.; SAFARI, H.; SHAFIE, H. (2012). Relationships Among Service Quality, Customer Satisfaction And Customer Perceived Value: Evidence From Iran's Software Industry. Journal of Management and Strategy, 3(3): 28-37. http://dx.doi.org/10.5430/jms.v3n3p28

RIGGLE, R.; EDMONDSON, D.; HANSEN, J. (2009). A Meta-analysis of the relationship between perceived organizational support and job outcomes: 20 years of research. Journal of Business Research, 62(10): 1027-1030. http://dx.doi.org/10.1016/j.jbusres.2008.05.003

RINGLE, C.M.; WENDE, S.; WILL, A. (2005). SmartPLS 2.0 (M3) Beta, Hamburg. Available at: http://www.smartpls.de.

RYU, K.; LEE, H.R.; KIM, W.G. (2012). The Influence Of The Quality Of The Physical Environment, Food, And Service On Restaurant Image, Customer Perceived Value, Customer Satisfaction, And Behavioral Intentions. International Journal of Contemporary Hospitality Management, 24(2): 200-223. http://dx.doi.org/10.1108/09596111211206141

SADEH, E.; MOUSAVI, L.; GARKAZ, M.; SADEH, S. (2011). The Structural Model of E-Service Quality, E-Customer Satsifaction, Trust, Customer Perceived Value and E-Loyalty. Australian Journal of Basic and Applied Sciences, 5(3): 532-538.

SAIBOU, H.; KEFAN, X. (2010). The Relationships Among Quality, Value, Satisfaction and Behavioral Intention in Health Care Provider Choice: A Study Based on the Case of Niger. IEEE, (6): 225-228. 2010, 2nd International Conference on Computer Engineering and Technology.

SANGEETHA, J.S.; MAHALINGAM, S. (2011). Service Quality Models In Banking: A Review. International Journal of Islamic and Middle Eastern Finance and Management, 4(1): 83-103. http://dx.doi.org/10.1108/17538391111122221

SANTOS, J. (2003). E-service quality: A model of virtual service quality imensions. Managing service Quality, 13(3): 233-246. http://dx.doi.org/10.1108/09604520310476490

SARSTEDT, M.; SCHLODERER, M.P. (2010). Developing a measurement approach for reputation of non-profit organizations. International Journal of Nonprofit and Voluntary Sector Marketing, 15(3): 276-299.

SEKARAN, U.; BOUGIE, R. (2010). Research Methods for Business: A Skill Building Approach. New York: John Wiley \& Sons, Inc.

SERRA, D.; SERNEELS, P.; BARR, A. (2011). Intrinsic motivations and the non-profit health sector: Evidence from Ethiopia. Personality and Individual Differences, 51(3): 309-314. http://dx.doi.org/10.1016/j.paid.2010.04.018

SHAHIN, A.; SAMEA, M. (2010). Developing the models of service quality gaps: A critical discussion. Business Management and Strategy, 1: 1-11. http://dx.doi.org/10.5296/bms.v1i1.395 
SHETH, J.N.; NEWMAN, B.I.; GROSS, B.I. (1991). Consumption Values and Market Choice. Cincinnati: South Western Publishing Company.

SIDDIQI, K.O. (2011). Interrelations between Service Quality Attributes, Customer Satisfaction And Customer Loyalty in the Retail Banking Sector in Bangladesh. International Journal of Business and Management, 6(3): 12-36. http://dx.doi.org/10.5539/ijbm.v6n3p12

STEVEN, A.B.; DONG, Y.; DRESNER, M. (2012). Linkages Between Customer Service, Customer Satisfaction And Performance In The Airline Industry: Investigation Of NonLinearities And Moderating Effects Transportation Research Part E. Logistics and Transportation Review, 48(4): 743-754. http://dx.doi.org/10.1016/j.tre.2011.12.006

SULTAN, P.; WONG H.Y. (2010). Service Quality In Higher Education - A Review And Research Agenda. International Journal of Quality and Service Sciences, 2(2): 259-272.

http://dx.doi.org/10.1108/17566691011057393

SURESHCHANDAR, G.S.; RAJENDRAN, C.; ANANTHARAMAN, R.N. (2002). The relationship between service quality and customer satisfaction - a factor specific approach. Journal of Services Marketing, 16(4): 363-379. http://dx.doi.org/10.1108/08876040210433248

SWEENEY, J.C.; SOUTAR, G.N.; JOHNSON, L.W. (1997). Retail service quality and perceived value. Journal of Consumer Services, 4(1): 39-48. http://dx.doi.org/10.1016/S09696989(96)00017-3

TUNG, L.L. (2004). Service quality and perceived value's impact on satisfaction, intention and usage of short message service (SMS). Information Systems Frontiers, 6(4): 353-368. http://dx.doi.org/10.1023/B:ISFI.0000046377.32617.3d

TURKYILMAZ, A.; AKMAN, G.; OZKAN, C.; PASTUSZAK, Z. (2011). Empirical Study of Public Sector Employee Loyalty and Satisfaction. Industrial Management \& Data Systems, 111(5): 675-696. http://dx.doi.org/10.1108/02635571111137250

VARKI, S.; COLGATE, M. (2001). The role of price perceptions in an integrated model of behavioural intentions. Journal of Service Research, 3(3): 232-240.

http://dx.doi.org/10.1177/109467050133004

WALKER, R.H.; JOHNSON, L.W.; LEONARD, S. (2006). Re-thinking the conceptualization of customer value and service quality within the service-profit chain. Managing Service Quality, 16(1): 23-36. http://dx.doi.org/10.1108/09604520610639946

WANG, Y.; LO, H.; YANG, Y. (2004). An integrated framework for service quality, customer value, satisfaction: Evidence from China's telecommunication industry. Information Systems Frontiers, 6(4): 325-340. http://dx.doi.org/10.1023/B:ISFI.0000046375.72726.67 
WETZELS, M.; ODEKERKEN-SCHRODER, G.; VAN OPPEN, C. (2009). Using PLS path modeling for assessing hierarchical construct models: Guidelines and empirical illustration. MIS Quarterly, 33(1): 177-195.

WILliAMS, P.; NAUMANN, E. (2011). Customer Satisfaction And Business Performance: A FirmLevel Analysis. Journal of Services Marketing, 25(1): 20-32.

http://dx.doi.org/10.1108/08876041111107032

YOGESH, P.; SATYANARAYANA, T.C. (2013). Dimensions Of Hospital Service Quality: A Critical Review Perspective of patients from global studies. International Journal of Health Care Quality Assurance, 26(4): 308-340. http://dx.doi.org/10.1108/09526861311319555

ZEITHAML, V.A. (1988). Consumer perceptions of price, quality, and value: A means-end model and synthesis of evidence. Journal of Marketing, 52(July): 2-22.

http://dx.doi.org/10.2307/1251446

Intangible Capital, 2014 (www.intangiblecapital.org)

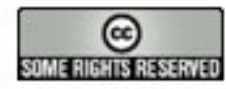

Article's contents are provided on a Attribution-Non Commercial 3.0 Creative commons license. Readers are allowed to copy, distribute and communicate article's contents, provided the author's and Intangible Capital's names are included. It must not be used for commercial purposes. To see the complete license contents, please visit http://creativecommons.org/licenses/by-nc/3.0/. 